\title{
Strong atmospheric new particle formation in winter in urban Shanghai, China
}

\author{
S. Xiao ${ }^{1,2}$, M. Y. Wang ${ }^{1,2}$, L. Yao ${ }^{1,2}$, M. Kulmala ${ }^{3}$, B. Zhou ${ }^{1,2}$, X. Yang ${ }^{1,2}$, J. M. Chen ${ }^{1,2}$, D. F. Wang ${ }^{4}$, Q. Y. Fu ${ }^{4}$, \\ D. R. Worsnop ${ }^{5}$, and L. Wang ${ }^{1,2}$
}

${ }^{1}$ Shanghai Key Laboratory of Atmospheric Particle Pollution and Prevention (LAP ${ }^{3}$ ), Department of

Environmental Science and Engineering, Fudan University, Shanghai 200433, China

${ }^{2}$ Fudan Tyndall Centre, Fudan University, Shanghai 200433, China

${ }^{3}$ Department of Physics, University of Helsinki, 00014 Helsinki, Finland

${ }^{4}$ Shanghai Environmental Monitoring Center, Shanghai 200030, China

${ }^{5}$ Aerodyne Research, Billerica, MA 01821, USA

Correspondence to: L. Wang (lin_wang@ fudan.edu.cn)

Received: 6 September 2014 - Published in Atmos. Chem. Phys. Discuss.: 24 October 2014

Revised: 4 January 2015 - Accepted: 23 January 2015 - Published: 19 February 2015

\begin{abstract}
Particle size distributions in the range of 1.34$615 \mathrm{~nm}$ were recorded from 25 November 2013 to 25 January 2014 in urban Shanghai, using a combination of one nano condensation nucleus counter system, one nano scanning mobility particle sizer (SMPS), and one longSMPS. Measurements of sulfur dioxide by an $\mathrm{SO}_{2}$ analyzer with pulsed UV fluorescence technique allowed calculation of sulfuric acid proxy. In addition, concentrations of ammonia were recorded with a differential optical absorption spectroscopy. During this 62-day campaign, 13 new particle formation (NPF) events were identified with strong bursts of sub-3 $\mathrm{nm}$ particles and subsequent fast growth of newly formed particles. The observed nucleation rate $\left(J_{1.34}\right)$, formation rate of $3 \mathrm{~nm}$ particles $\left(J_{3}\right)$, and condensation sink were $112.4-271.0 \mathrm{~cm}^{-3} \mathrm{~s}^{-1}, 2.3-$ $19.2 \mathrm{~cm}^{-3} \mathrm{~s}^{-1}$, and $0.030-0.10 \mathrm{~s}^{-1}$, respectively. Subsequent cluster/nanoparticle growth (GR) showed a clear size dependence, with average values of $\mathrm{GR}_{1.35 \sim 1.39}, \mathrm{GR}_{1.39 \sim 1.46}$,

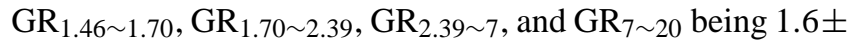
$1.0,1.4 \pm 2.2,7.2 \pm 7.1,9.0 \pm 11.4,10.9 \pm 9.8$, and $11.4 \pm$ $9.7 \mathrm{~nm} \mathrm{~h}^{-1}$, respectively. Correlation between nucleation rate $\left(J_{1.34}\right)$ and sulfuric acid proxy indicates that nucleation rate $J_{1.34}$ was proportional to a $0.65 \pm 0.28$ power of sulfuric acid proxy, indicating that the nucleation of particles can be explained by the activation theory. Correlation between nucleation rate $\left(J_{1.34}\right)$ and gas-phase ammonia suggests that ammonia was associated with NPF events. The calculated
\end{abstract}

sulfuric acid proxy was sufficient to explain the subsequent growth of $1.34-3 \mathrm{~nm}$ particles, but its contribution became smaller as the particle size grew. Qualitatively, NPF events in urban Shanghai likely occur on days with low levels of aerosol surface area, meaning the sulfuric acid proxy is only a valid predictor when aerosol surface area is low.

\section{Introduction}

Aerosol particles can influence climate directly and indirectly (Andreae and Crutzen, 1997; Haywood and Boucher, 2000; IPCC, 2013), and have adverse impact on human health (Dockery et al., 1993; Laden et al., 2006; Pope and Dockery, 2006). Atmospheric nucleation of gas-phase precursors to clusters and then further to nanoparticles is the largest source of atmospheric aerosol particles (Kulmala et al., 2004b; Zhang et al., 2012). This phenomenon has been observed in numerous locations around the world, including areas with a pristine atmosphere, e.g., coastal areas (O'Dowd et al., 2002), Antarctic/Arctic (Park et al., 2004), remote forest (Dal Maso et al., 2005), semi-rural locations with very low pollution levels such as Kent, $\mathrm{OH}$ (Kanawade et al., 2012), and heavily polluted cities, such as Mexico City (Dunn et al., 2004).

The exact mechanism for atmospheric nucleation is still under active investigation. Field measurements and labora- 
tory studies have shown that sulfuric acid is a key precursor species for atmospheric nucleation (Weber et al., 1996; Sipila et al., 2010) and that atmospheric nucleation rate can be significantly promoted in the presence of other precursors including ammonia (Ball et al., 1999; Benson et al., 2009), amines (Berndt et al., 2010; Zhao et al., 2011), and organic acids (Zhang et al., 2004, 2009). At certain locations, ioninduced nucleation (Yu and Turco, 2001; Lee et al., 2003) or iodine species (O'Dowd et al., 2002) may also help to explain the observed new particle formation. Very recently, progress has been made by the use of a particle size magnifier (PSM) and chemical ionization atmospheric pressure interface timeof-flight mass spectrometer by combining the Cosmics Leaving OUtdoor Droplets (CLOUD) chamber experiments and ambient observations including those in Hyytiälä, Finland, showing that oxidation products of biogenic emissions, together with sulfuric acid, contribute to new particle formation in the atmosphere (Schobesberger et al., 2013; Riccobono et al., 2014).

China suffers severe air pollution, especially high atmospheric particle loadings in recent years (Chan and Yao, 2008). Among many potential sources of atmospheric particles, atmospheric nucleation has been suggested to be a significant source of particles (Matsui et al., 2011; Yue et al., 2011). Correspondingly, a number of extensive campaigns or long-term observational studies have been carried out in the Beijing area (e.g., Wu et al., 2007; Yue et al., 2009; Zhang et al., 2011; Gao et al., 2012) and Pearl River delta, including Hong Kong (e.g., Guo et al., 2012; Yue et al., 2013). As one of the most industrialized area of China, one of the most populated region in the world, and one of the hotspots for particle pollution, Yangtze River delta (YRD) has only seen a few research activities on atmospheric nucleation (Du et al., 2012; Herrmann et al., 2014). Among the few studies, measurements at the station for Observing Regional Processes of the Earth System, Nanjing University (SORPES-NJU), offered a first insight for new particle formation in the western part of YRD (Herrmann et al., 2014). On the other hand, atmospheric nucleation research in China is still in its infant stage and the latest experimental techniques are yet to be applied in China. For example, data on freshly nucleated particles are really sparse, except for those from an air ion spectrometer employed at SORPES-NJU (Herrmann et al., 2014). To the best of our knowledge, the use of a PSM, which is able to study atmospheric nucleation at the size (mobility diameter) down to $1.5 \pm 0.4 \mathrm{~nm}$ (Kulmala et al., 2012), has not been reported in a Chinese location in literature. The lack of key information greatly hinders a better understanding of nucleation mechanisms in China, where concentrations of sulfuric acid and basic gases including ammonia and amines are high (Zheng et al., 2011, 2015) but concentrations of extremely low-volatility organic compounds formed from biogenic emissions are yet to be determined.

Direct measurements of atmospheric nucleation rates down to $1.5 \pm 0.4 \mathrm{~nm}$ provide a better and more accurate char- acterization of atmospheric nucleation; the indirect calculation of atmospheric nucleation rates from the formation rates of $3 \mathrm{~nm}$ particles leads to substantial uncertainty due to our incomplete understanding of condensational growth and coagulation scavenging of particles in the 1.5 to $3 \mathrm{~nm}$ range (Anttila et al., 2010; Korhonen et al., 2011). With the growing number of reports of real nucleation rates in clean atmosphere (e.g., Kulmala et al., 2012; Yu et al., 2014), it is ideal to measure nucleation rates in a polluted urban atmosphere to find out how atmospheric nucleation rates vary under different atmospheric conditions. In addition, the nucleation mechanism in a polluted urban atmosphere, which is vital to understanding atmospheric nucleation at a global scale and for atmospheric model development, can be preliminarily investigated by examining the relationship between the measured atmospheric nucleation rates and the well-accepted precursor gases that exist in high concentrations.

In this study, we measured atmospheric nucleation from 25 November 2013 to 25 January 2014 in urban Shanghai with a nano condensation nucleus counter system (nCNC) and two sets of scanning mobility particle sizers (SMPS). Nucleation frequency, nucleation rate $\left(J_{1.34}\right)$, condensation sink (CS), and growth rates (GR) are reported and compared with previous studies with similar or dissimilar atmospheric environments. In addition, the potential nucleation mechanism was explored by correlating sulfuric acid proxy calculated from sulfur dioxide precursor and gas-phase ammonia to nucleation rate $J_{1.34}$.

\section{Experimental}

\subsection{Nucleation measurements}

Nucleation measurements were carried out on the rooftop of a teaching building $\left(31^{\circ} 18^{\prime} \mathrm{N}, 121^{\circ} 30^{\prime} \mathrm{E}\right)$ that is about $20 \mathrm{~m}$ above ground on the campus of Fudan University between 25 November 2013 and 25 January 2014. This monitoring site is mostly surrounded by commercial properties and residential dwellings. The Middle Ring Road, one of the main overhead highways in Shanghai, lies about $100 \mathrm{~m}$ to the south of the site. Hence, the Fudan site can be treated as a representative urban site influenced by a wide mixture of emission sources (Wang L. et al., 2013; Ma et al., 2014).

Ambient particle size distributions in the range of 1.34$615 \mathrm{~nm}$ were measured using a combination of one nano condensation nucleus counter system (model A11, Airmodus, Finland), one nano-SMPS (consisting of one DMA3085 and one CPC 3776, TSI, USA), and one long-SMPS (consisting of one DMA3081 and one CPC3775, TSI, USA). The instruments were continuously running except for maintenance and minor instrument breakdown during the campaign.

Ambient air was drawn into a stainless-steel manifold of $5.0 \mathrm{~m}$ length and $4 \mathrm{inch}$ inner diameter at a flow rate of 153 cubic feet per minute (CFM) using a blower (Model 
DJT10U-25M, NUSSUN, China). From this main manifold, 1.75 $\mathrm{L} \mathrm{min}^{-1}$ ambient air was drawn through a $1 / 4$ in. inner diameter stainless-steel tube of $18 \mathrm{~cm}$ length, and diluted with a zero air flow generated by a zero air generator (Model 111, Thermo, USA) at a ratio of $1: 1$ to reduce the overall relative humidity $(\mathrm{RH})$ and the number of particles entering PSM, since high RH and particle loading had an impact on the saturation of diethylene glycol in PSM and hence data quality. Subsequently, $2.5 \mathrm{~L} \mathrm{~min}^{-1}$ diluted air was sampled into nCNC. In addition, $30 \mathrm{~L} \mathrm{~min}^{-1}$ split flow was drawn from the main manifold through a $1 / 4$ in. inner diameter conductive silicon tubing of $50 \mathrm{~cm}$ length, and then 0.3 and $1.5 \mathrm{~L} \mathrm{~min}^{-1}$ ambient air from the split flow were drawn into nano-SMPS and long-SMPS, respectively. The calculated diffusion loss is up to $29 \%$ for $1.35 \mathrm{~nm}$ particles with the above setup and has been taken into account in the entire size range during data processing.

The nCNC system consists of one PSM (model A10, Airmodus, Finland) and one butanol Condensation Particle Counter (model A20, Airmodus, Finland), and was used to measure size distributions of $1.34-3 \mathrm{~nm}$ clusters/particles. Briefly, PSM activates the smallest particles using diethylene glycol as a working fluid and condensationally grows nanoparticles up to larger than $90 \mathrm{~nm}$ in mobility equivalent diameter, after which an external condensation particle counter is used to further grow the particles to optical sizes and count the grown particles (Vanhanen et al., 2011). In this study, PSM was used in the scanning mode in which the saturator flow rate is changed continuously, giving an activation spectrum of the measured particles to obtain size distribution of sub-3 nm clusters/particles. A scanning cycle of 100 steps between saturator flow rates 0.1 and $1 \mathrm{~L} \mathrm{~min}^{-1}$ and a time resolution of $220 \mathrm{~s}$ were chosen. Sub- $3 \mathrm{~nm}$ clusters/particles were classified into 5 bins, i.e., 1.34-1.37, 1.37-1.41, 1.41$1.52,1.52-1.89$, and 1.89-3.0 nm. Geometric mean values of upper and lower limits of the five bins, i.e., 1.35, 1.39, 1.46, 1.70 , and $2.39 \mathrm{~nm}$, were used to refer to the five bins, respectively, in the growth rate calculation.

The nano-SMPS measured particles in the size range of 3 to $64 \mathrm{~nm}$ and the long-SMPS recorded particles from 14 to $615 \mathrm{~nm}$. For both SMPSs, 64 size bins and $5 \mathrm{~min}$ time resolution were chosen. The sample flow to sheath flow ratios for both SMPSs were set at $1: 10$. A comparison analysis on the total particle concentrations between 14 and $64 \mathrm{~nm}$ measured by both nano-SMPS and long-SMPS showed less than $10 \%$ difference in the size range of 55-64 $\mathrm{nm}$ between two SMPSs. Hence, number concentrations of particles in the size range of 3-615 nm, $N_{3 \sim 615}$, were calculated from the sum of $N_{3} \sim 55$ obtained from nano-SMPS, $N_{55 \sim 64}$ from the arithmetic average of nano-SPMS and long-SMPS, and $N_{64 \sim 615}$ from long-SMPS.

At the same site, sulfur dioxide $\left(\mathrm{SO}_{2}\right)$ was measured by an $\mathrm{SO}_{2}$ analyzer with pulsed UV fluorescence technique (Model 43i, Thermo, USA) and a time resolution of $5 \mathrm{~min}$; calibration of this $\mathrm{SO}_{2}$ analyzer was performed every month. A dif- ferential optical absorption spectroscopy system was used to measure the integrated concentration of $\mathrm{NH}_{3}$ along the optical path between a transmitter telescope using a $35 \mathrm{~W}$ Deuterium lamp as the light source and a receiver telescope $(53 \mathrm{~m})$; then the system yielded the average concentration of $\mathrm{NH}_{3}$ by dividing the integrated concentration by the absorption length (Platt and Stutz, 2008). In this study, the concentration of $\mathrm{NH}_{3}$ was determined by fitting the reference spectra to the atmospheric spectra in a given window (205$220 \mathrm{~nm}$ ) using a nonlinear least-squares method similar to a previous measurement of $\mathrm{HONO}$ and $\mathrm{NO}_{2}$ (Wang S. et al., 2013). Detection limit of $\mathrm{NH}_{3}$ was about $1 \mathrm{ppb}$ with a 3 min integration time.

Solar radiation intensity measured by a pyranometer (Kipp \& Zonen CMP6, Netherlands) was obtained from the Shanghai Pudong Environmental Monitoring Centre $\left(31^{\circ} 14^{\prime} \mathrm{N}\right.$, $121^{\circ} 32^{\prime} \mathrm{E}$, about $8.78 \mathrm{~km}$ from the Fudan site).

\subsection{Data processing}

\subsubsection{Nucleation rate, formation rate of $3 \mathrm{~nm}$ particles $\left(J_{3}\right)$, growth rate, and condensation sink}

In this study, PSM allowed measurements of clusters/particles down to $1.34 \mathrm{~nm}$. Hence, atmospheric nucleation rate, $J_{1.34}$, defined as the flux of particles growing over $1.34 \mathrm{~nm}$, can be calculated by taking into account the coagulation losses and condensational growth out of the considered size range (Kulmala et al., 2012):

$$
\begin{aligned}
& J_{1.34}=\frac{\mathrm{d} N_{1.34 \sim 3}}{\mathrm{~d} t}+\operatorname{Coag} S_{d_{\mathrm{p}}=2 \mathrm{~nm}} \cdot N_{1.34 \sim 3}+\frac{1}{1.66 \mathrm{~nm}} \\
& \mathrm{GR}_{1.34 \sim 3} \cdot N_{1.34 \sim 3},
\end{aligned}
$$

where $\operatorname{Coag} S_{d_{\mathrm{p}=2 \mathrm{~nm}}}$ represents coagulation sink of $2 \mathrm{~nm}$ particles, an approximation for that of the size interval 1.34$3 \mathrm{~nm}$, and $\mathrm{GR}_{1.34 \sim 3}$ represents the apparent clusters/particle growth rate between 1.34 and $3 \mathrm{~nm}$.

Formation rate of $3 \mathrm{~nm}$ particles was calculated in a similar way (Sihto et al., 2006; Kulmala et al., 2012), providing a comparison with previous studies:

$J_{3}=\frac{\mathrm{d} N_{3 \sim 6}}{\mathrm{~d} t}+\operatorname{Coag} S_{d_{\mathrm{p}}=4 \mathrm{~nm}} \cdot N_{3 \sim 6}+\frac{1}{3 \mathrm{~nm}} \mathrm{GR}_{3 \sim 6} \cdot N_{3 \sim 6}$,

where $\operatorname{Coag} S_{d_{\mathrm{p}=4 \mathrm{~nm}}}$ represents coagulation sink of $4 \mathrm{~nm}$ particles, an approximation for that of the size interval 3-6 nm.

Growth rate is defined as the rate of change in the diameter of a growing particle population, using the maximumconcentration method (Kulmala et al., 2012):

$\mathrm{GR}=\frac{d d_{\mathrm{p}}}{\mathrm{d} t}=\frac{\Delta d_{\mathrm{p}}}{\Delta \mathrm{t}}=\frac{d_{\mathrm{p}_{2}}-d_{\mathrm{p}_{1}}}{t_{2}-t_{1}}$,

where $d_{\mathrm{p}_{1}}$ and $d_{\mathrm{p}_{2}}$ are the representative particle diameters at times $t_{1}$ and $t_{2}$, respectively. 
Condensation sink describes the condensing vapor sink caused by the particle population (Kulmala et al., 2012):

$\mathrm{CS}=4 \pi D \int_{0}^{d_{\mathrm{p} m a x}} \beta_{m, d_{\mathrm{p}}} d_{\mathrm{p}} N_{d_{\mathrm{p}}} d d_{\mathrm{p}}=4 \pi D \sum_{d_{\mathrm{p}}} \beta_{m, d_{\mathrm{p}}} d_{\mathrm{p}} N_{d_{\mathrm{p}}}$,

where $D$ is the diffusion coefficient of the condensing vapor, usually assumed to be sulfuric acid $\left(0.104 \mathrm{~cm}^{2} \mathrm{~s}^{-1}\right.$ used in this study), and $\beta_{m, d_{\mathrm{p}}}$ is the transitional regime correction factor.

\subsubsection{Sulfuric acid}

Sulfuric acid has been accepted as a key gas-phase precursor for atmospheric nucleation and contributes to the subsequent growth of newly formed particles (Weber et al., 1996; Sipila et al., 2010). The accurate measurement of gas-phase sulfuric acid requires application of chemical ionization mass spectrometry using nitrates as reagent ions (Eisele and Tanner, 1993), which was not possessed by this research group during this study. Instead, the sulfuric acid proxy $\left[\mathrm{H}_{2} \mathrm{SO}_{4}\right]$ was estimated based on local solar radiation $n$ level radiation, $\mathrm{SO}_{2}$ concentration $\left[\mathrm{SO}_{2}\right.$ ], condensation sink, and relatively humidity (Mikkonen et al., 2011):

$$
\begin{aligned}
& {\left[\mathrm{H}_{2} \mathrm{SO}_{4}\right]=8.21 \times 10^{-3} \cdot k \cdot \text { radiation } \cdot\left[\mathrm{SO}_{2}\right]^{0.62}} \\
& \cdot(\mathrm{CS} \cdot \mathrm{RH})^{-0.13}
\end{aligned}
$$

where $k$ is the temperature-dependent reaction-rate constant. The relative error between calculated sulfuric acid proxy and measured sulfuric acid concentration is estimated to be $42 \%$ (Mikkonen et al., 2011). The time resolution of calculated sulfuric acid proxy was $1 \mathrm{~h}$ since that of temperature and relative humidity was 1 .

Condensation of sulfuric acid contributes to the growth of newly formed particles. The growth of clusters/particles due to condensation of sulfuric acid, $\mathrm{GR}_{\mathrm{H}_{2} \mathrm{SO}_{4}}$, can be estimated by the following equations (Nieminen et al., 2010):

$$
\begin{aligned}
& \mathrm{GR}_{\mathrm{H}_{2} \mathrm{SO}_{4}}=\frac{\gamma}{2 \rho_{\mathrm{v}}}\left(1+\frac{d_{\mathrm{v}}}{d_{\mathrm{p}}}\right)^{2}\left(\frac{8 k T}{\pi}\right)^{1 / 2} \\
& \left(\frac{1}{m_{\mathrm{p}}}+\frac{1}{m_{\mathrm{v}}}\right)^{1 / 2} m_{\mathrm{v}}\left[\mathrm{H}_{2} \mathrm{SO}_{4}\right]
\end{aligned}
$$

and

$\gamma=\frac{4}{3} \cdot K n \cdot \beta_{m, d_{\mathrm{p}}}$

where $\rho_{\mathrm{v}}$ and $d_{\mathrm{v}}$ are the condensed phase density and molecule diameter of $\mathrm{H}_{2} \mathrm{SO}_{4}$, respectively; $m_{\mathrm{p}}$ and $m_{\mathrm{v}}$ are particle and $\mathrm{H}_{2} \mathrm{SO}_{4}$ vapor molecule masses, respectively; $\gamma$ is a correction factor; and $K n$ is the Knudsen number (Lehtinen and Kulmala, 2003). For this calculation, particle density $\rho_{\mathrm{p}}=1.83 \mathrm{~g} \mathrm{~cm}^{-3}$ was used.
The particle growth due to the hydration of $\mathrm{H}_{2} \mathrm{SO}_{4}$ is taken into account by assuming that sulfuric acid is instantaneously equilibrated with gas-phase water. During our campaign, daily average $\mathrm{RH}$ varied between 28.7 and $60.0 \%$. Hence, using the $\mathrm{H}_{2} \mathrm{SO}_{4}$-hydrate distribution data given by Kurtén et al. (2007), the density and mass of the average hydrated $\mathrm{H}_{2} \mathrm{SO}_{4}$ molecule at $50 \%$ relative humidity is calculated and further used in Eq. (6).

\section{Results and discussion}

\subsection{Classification of new particle formation (NPF) events}

Figure 1 presents a contour plot for particle size distributions of 3-615 nm and a number concentration plot of sub3 nm clusters/particles, $N_{1.34 \sim 3}$, during 25 November 2013 25 January 2014. Data were occasionally missing because of maintenance and minor breakdown of instruments. From the figure, frequent bursts of sub- $3 \mathrm{~nm}$ particles were evident, with concentrations up to $8.0 \times 10^{4} \mathrm{~cm}^{-3}$ around noontime. However, similar to previous studies (Kulmala et al., 2007, 2013; Yu et al., 2014), not all sub-3 nm particles eventually underwent a continuous growth to larger sizes. In this study, we define an observation day with appearances of sub- $3 \mathrm{~nm}$ clusters/particles over a time span of hours and subsequent growth to larger sizes for a few hours as a NPF event day. In this case, a NPF day will present a banana-shaped contour plot of particle size distributions obtained from SMPS (Dal Maso et al., 2005). We focus on characteristics and potential mechanisms of these events.

According to the classification, there were 13 event days during the 62-day campaign, as illustrated by the shadow in Fig. 1. Although nCNC data were partially unavailable on 26 December 2013 and completely unavailable on 24 January 2014, these 2 days are still defined as NPF days since a distinctive banana-shaped contour plot for particle distributions between 3 and $615 \mathrm{~nm}$ existed. 18 December 2013 was not regarded as a NPF day since $N_{1.34 \sim 3}$ was not recorded and the growth of 3-20 nm particles was relatively short-lived.

Among these NPF events, five NPF events occurred in November, three in December, and five in January. The averaged frequency for NPF events was $21.0 \%$ during the 62 day campaign. Our NPF frequency in Shanghai is larger than the average value in winter 1996-2003 at SMEAR II station, Hyytiälä, Finland (Dal Maso et al., 2005), likely because nucleation events in Hyytiälä have recently been related to oxidation products of biogenic emissions (Kulmala et al., 1998; Schobesberger et al., 2013; Riccobono et al., 2014) and photochemistry of volatile organic compounds is less intensive in winter months. This frequency is also higher than that in winter in semi-rural Kent, $\mathrm{OH}$, during which transport of sulfur dioxide from the east-southeast power plant to Kent is not favored (Kanawade et al., 2012). NPF events occurred 


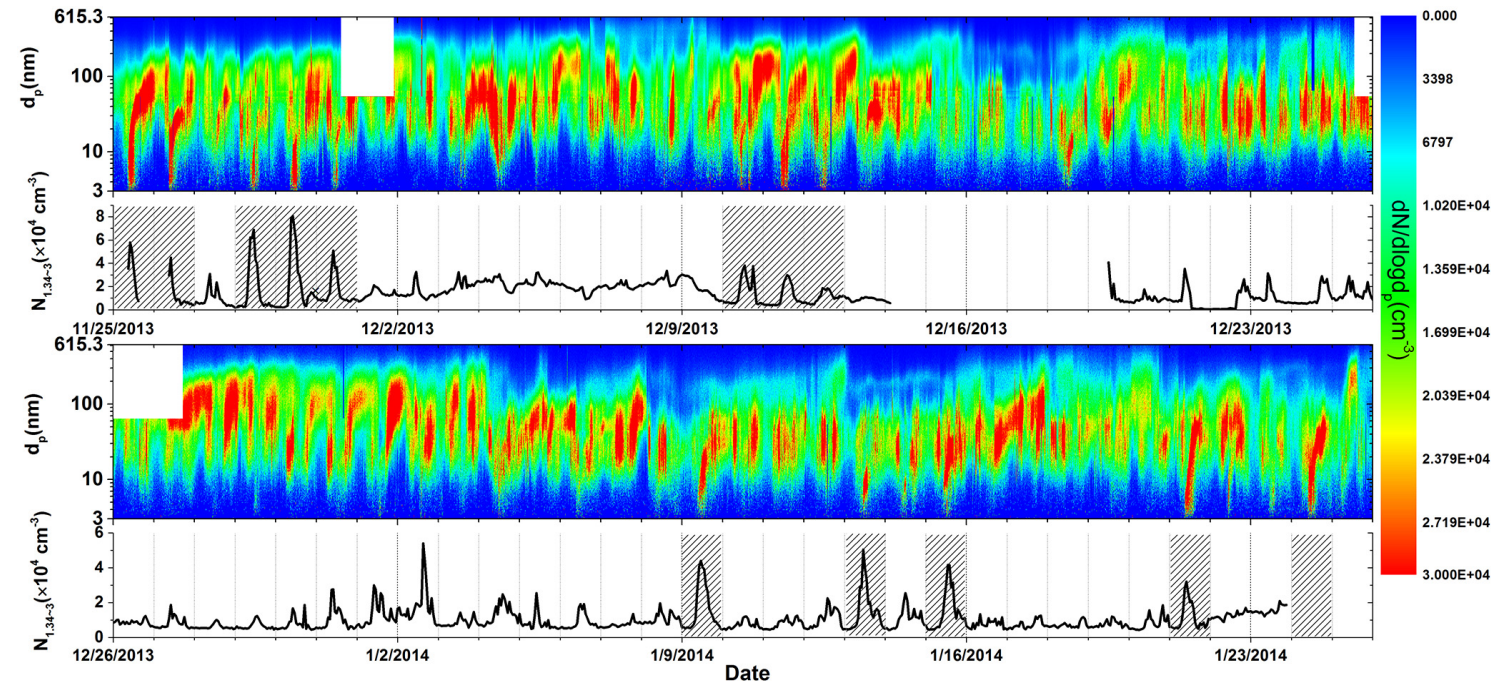

Figure 1. Contour plot for particle size distributions of 3-615 nm and plot of number concentrations of sub-3 nm clusters/particles $\left(N_{1.34 \sim 3}\right)$ during 25 November 2013-25 January 2014. Data were occasionally missing because of the maintenance and minor breakdown of instruments. NPF events are illustrated with shadows.

at a frequency of around $40 \%$ during November-December 2004 in Beijing (Wu et al., 2007), much more often than in Shanghai. On the other hand, NPF frequency in Shanghai is remarkably close to that measured in winter 2012 in Nanjing, which is also located in YRD (Herrmann et al., 2014).

Number concentrations of particles in different size ranges, i.e., $N_{1.34 \sim 3}, N_{3 \sim 7}$, and $N_{7 \sim 30}$, respectively, on a NPF day (11 December 2013) and an obvious non-NPF day (7 January 2014) are further examined to illustrate features of a NPF event, as shown in Fig. 2. On the NPF day, 1.34$3 \mathrm{~nm}$ particles appeared as early as 7 a.m. UTC +8 in the morning, i.e., right after sunrise $(6: 42$ a.m. UTC +8 on 11 December 2013), reached its maximum just before noontime, and spanned for almost the whole daytime (sunset at 4:52 p.m., 11 December 2013), suggesting that photochemistry products likely contribute to the formation of smallest particles. This size distribution of atmospheric neutral and charged clusters/particles by a scanning PSM is identical to that measured in Hyytiälä, Finland (Kulmala et al., 2013). On the same NPF day, 3-7 and 7-30 nm particles appeared much later, resembling previous findings only with SMPS measurements (e.g., Yue et al., 2010). The lag in peaking times of $N_{1.34 \sim 3}, N_{3 \sim 7}$, and $N_{7 \sim 30}$ on the NPF day clearly indicated the continuous growth of clusters/particles, the reduction of particles due to coagulation during the growth, and the diverse sources of particles in the size range of $7-30 \mathrm{~nm}$. In contrast, $N_{1.34 \sim 3}$ and $N_{3 \sim 7}$ showed a flat profile on the nonNPF day. The minor enhancement in $N_{7 \sim 30}$ between 10 a.m. and 5 p.m. on the non-NPF day was not due to growth of newly formed particles. Instead, direct emission of 7-30 nm particles from transportation activity likely explained their appearance.

\subsection{General characteristics of NPF events}

Table 1 summaries characteristics of each NPF event observed in this campaign, including $J_{1.34}, J_{3}, \mathrm{GR}_{1.35 \sim 2.39}$ (from the bin of 1.34-1.37 nm to the bin of $1.890-3.0 \mathrm{~nm}$ ), $\mathrm{GR}_{2.39 \sim 7}, \mathrm{GR}_{7 \sim 20}, \mathrm{CS},\left[\mathrm{H}_{2} \mathrm{SO}_{4}\right], N_{1.34 \sim 3}$, and total number concentrations of particles $N_{1.34 \sim 615}$, and compares the mean values to those in selected other studies. Nucleation rate $J_{1.34}$ and formation rate of $3 \mathrm{~nm}$ particles were 112.4-271.0 and $2.3-19.2 \mathrm{~cm}^{-3} \mathrm{~s}^{-1}$, respectively. Nucleation rate $J_{1.34}$ in Shanghai is obviously significantly larger than $1.4 \mathrm{~cm}^{-3} \mathrm{~s}^{-1}$ in Hyytiälä, Finland with a pristine atmosphere (Kulmala et al., 2012) and $1.3 \mathrm{~cm}^{-3} \mathrm{~s}^{-1}$ in Kent, $\mathrm{OH}$, with relatively lower levels of pollutants (Yu et al., 2014). Direct comparison of our nucleation rate with that in a Chinese location is not feasible because no previous reports are available. However, Herrmann et al. (2014) reported a $J_{2}$ of $33.2 \mathrm{~cm}^{-3} \mathrm{~s}^{-1}$ at the SORPES-NJU station in Nanjing, China. Together with their results, we conclude that strong nucleation events occur geographically widely in the YRD region.

Formation rate of $3 \mathrm{~nm}$ particles has been more routinely reported. Similarly to $J_{1.34}, J_{3}$ in Shanghai is significantly larger than $0.61 \mathrm{~cm}^{-3} \mathrm{~s}^{-1}$ in Hyytiälä, Finland (Kulmala et al., 2012), and generally comparable to 3.3-81.4 and 1.122.4 in Beijing (Wu et al., 2007; Yue et al., 2009), 3.6-6.9 in Hong Kong (Guo et al., 2012), and $2.4-4.0 \mathrm{~cm}^{-3} \mathrm{~s}^{-1}$ in a back-garden rural site in Pearl River delta (Yue et al., 2013). The fast reduction from $J_{1.34}$ to $J_{3}$ was likely due to the presence of a large background particle number as shown in Table 1 .

The large background particle number concentrations corresponded to the high condensation sink $\left(0.030-0.10 \mathrm{~s}^{-1}\right)$ observed during the campaign. As shown in Table 1, CS 


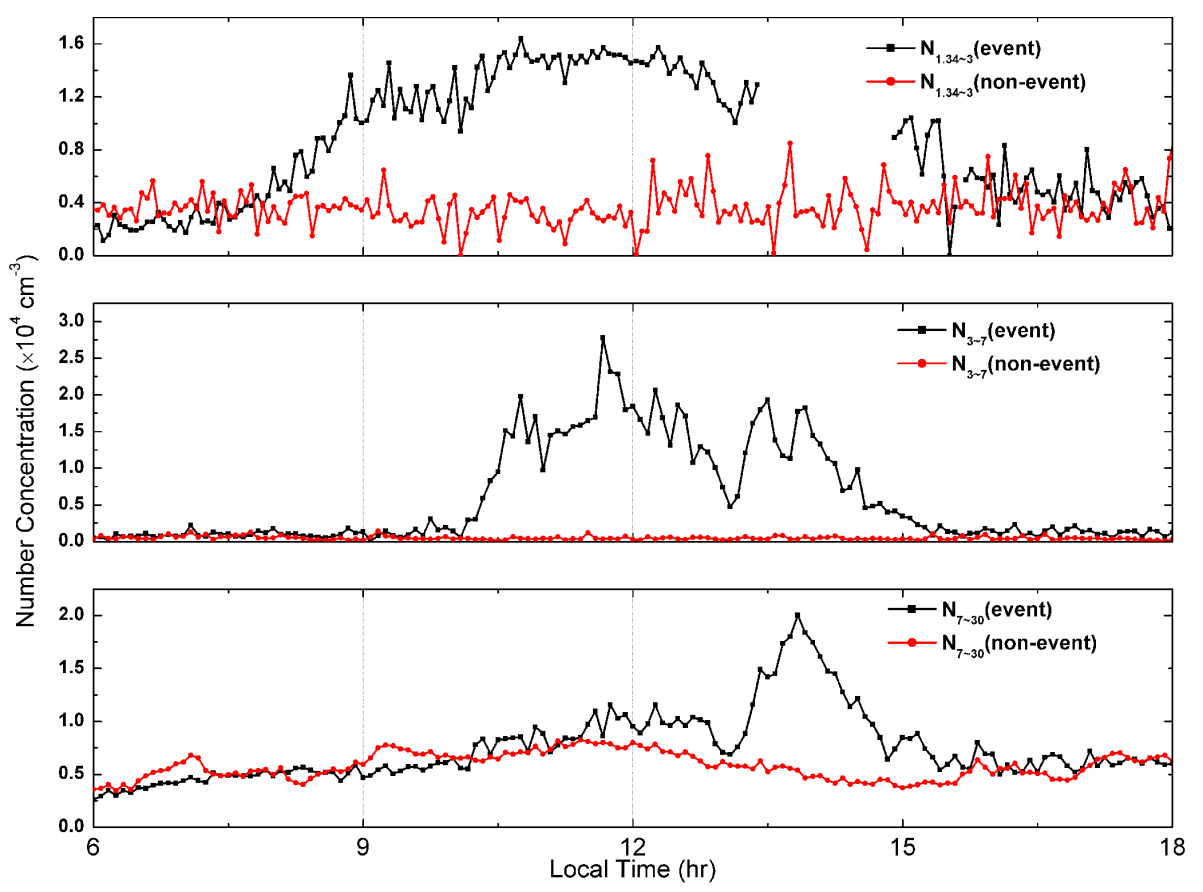

Figure 2. Profiles of $N_{1.34 \sim 3}, N_{3 \sim 7}$, and $N_{7 \sim 30}$ from 6 a.m. to 6 p.m. UTC +8 on a NPF day (11 December 2013) and a non-NPF day (7 January 2014).

in Shanghai is much larger than $(0.05-0.35) \times 10^{-2} \mathrm{~s}^{-1}$ in Hyytiälä, Finland (Kulmala et al., 2012), and $0.8 \times 10^{-2} \mathrm{~s}^{-1}$ in Kent, $\mathrm{OH}$ (Yu et al., 2014), but comparable to (0.588.4) $\times 10^{-2} \mathrm{~s}^{-1}$ in Beijing (Wu et al., 2007; Yue et al., 2009; Zhang et al., 2011; Gao et al., 2012), (1.0-6.2) $\times 10^{-2} \mathrm{~s}^{-1}$ in Hong Kong (Guo et al., 2012), $2.4 \times 10^{-2} \mathrm{~s}^{-1}$ in Nanjing (Herrmann et al., 2014), and (3.5-4.6) $\times 10^{-2} \mathrm{~s}^{-1}$ in an urban site in Pearl River delta (Yue et al., 2013). High sulfuric acid proxy $\left(\left[\mathrm{H}_{2} \mathrm{SO}_{4}\right]\right.$ of $(2.3-6.4) \times 10^{7}$ molecules $\left.\mathrm{cm}^{-3}\right)$ existed to promote the NPF events. Measurements of gas-phase sulfuric acid by a chemical ionization mass spectrometer during the CAREBeijing 2008 Campaign, a time period with strict air-quality control regulations, reported peak concentrations of sulfuric acid up to the order of $10^{7}$ molecules $\mathrm{cm}^{-3}$ (Zheng et al., 2011), smaller than our sulfuric acid proxy. Uncertainty may well exist for our sulfuric acid proxy that was calculated from the concentrations of sulfur dioxide and radiation intensity. However, judging from $\mathrm{CS}$ and $\left[\mathrm{H}_{2} \mathrm{SO}_{4}\right]$ together, it is clear that the condensable vapor in Shanghai is likely a main impetus for observed strong new particle formation events.

$\mathrm{GR}_{1.35 \sim 2.39}, G R_{2.39 \sim 7}$, and $\mathrm{GR}_{7 \sim 20}$ were in the range of $0.49-8.1,3.1-35.7$, and $4.5-38.3 \mathrm{~nm} \mathrm{~h}^{-1}$, respectively. The arithmetic average values of $\mathrm{GR}_{1.35 \sim 2.39}, \mathrm{GR}_{2.39 \sim 7}$, and $\mathrm{GR}_{7 \sim 20}$ were $2.0 \pm 2.7$ ( 1 standard deviation), $10.9 \pm 9.8$, and $11.4 \pm 9.7 \mathrm{~nm} \mathrm{~h}^{-1}$, respectively, which are comparable to $3-$ $20 \mathrm{~nm} \mathrm{~h}^{-1}$ for nucleation mode particles in another sulfurrich city, Atlanta, GA (Stolzenburg et al., 2005). In addition, $\mathrm{GR}_{1.35 \sim 2.39}$ in Shanghai is smaller than the growth rates $\left(5.5-7.6 \mathrm{~nm} \mathrm{~h}^{-1}\right)$ for particles in $1 \sim 3 \mathrm{~nm}$ geometric diameter range in Atlanta (Kuang et al., 2012). A closer examination of growth rates was performed by dividing $\mathrm{GR}_{1.35 \sim 2.39}$ into growth of clusters/particles from one bin to another, i.e., $\mathrm{GR}_{1.35 \sim 1.39}\left(1.6 \pm 1.0 \mathrm{~nm} \mathrm{~h}^{-1}\right.$ from the bin of 1.34 $1.37 \mathrm{~nm}$ to the bin of $1.37-1.41 \mathrm{~nm}), \mathrm{GR}_{1.39 \sim 1.46}(1.4 \pm$ $2.2 \mathrm{~nm} \mathrm{~h}^{-1}$ from $1.37-1.41$ to $\left.1.41-1.52 \mathrm{~nm}\right), \mathrm{GR}_{1.46 \sim 1.70}$ $\left(7.2 \pm 7.1 \mathrm{~nm} \mathrm{~h}^{-1}\right.$ from $1.41-1.52$ to $\left.1.52-1.89 \mathrm{~nm}\right)$, and $\mathrm{GR}_{1.70 \sim 2.39}\left(9.0 \pm 11.4 \mathrm{~nm} \mathrm{~h}^{-1}\right.$ from $1.52-1.89$ to 1.89 $3.0 \mathrm{~nm})$. These growth rates show a clear size-dependent particle growth (Fig. 3), owing to the nano-Köhler activation that suggests a faster growth for activated nanoparticles due to a decreasing Kelvin effect and, thus, an enhanced condensation flux (Kulmala et al., 2004b), Kelvin effect, and surface or volume-controlled reaction corrected for the Kelvin effect on surface or volume concentrations (Kuang et al., 2012). Similar observations have been reported in previous studies using nCNC (Kulmala et al., 2013) and diethylene glycolbased ultrafine condensation particle counter (DEG UCPC) (Kuang et al., 2012). Our $\mathrm{GR}_{2.39 \sim 7}$ is larger than $6.3 \mathrm{~nm} \mathrm{~h}^{-1}$ in Nanjing (Herrmann et al., 2014), and our $\mathrm{GR}_{7 \sim 20}$ is close to the upper bound of those in urban Beijing (Wu et al., 2007; Yue et al., 2009; Zhang et al., 2011; Gao et al., 2012) and generally larger than $1.5-8.4 \mathrm{~nm} \mathrm{~h}^{-1}$ in Hong Kong (Guo et al., 2012), indicating that high concentrations of condensable vapors existed. In addition, our growth rates suggest that the smallest clusters (the bin of $1.34-1.37 \mathrm{~nm}$ ), if not scavenged by larger particles, would grow to $3 \mathrm{~nm}$ within $\sim 12 \mathrm{~min}$ and to $20 \mathrm{~nm}$ within $\sim 2 \mathrm{~h}$. 
Table 1. Nucleation rate $\left(J_{1.34}\right)$, formation rate of $3 \mathrm{~nm}$ particles $\left(J_{3}\right)$, particle growth rates $\left(\mathrm{GR}_{1.35 \sim 2.39}, \mathrm{GR}_{2.39 \sim 7}\right.$, and $\left.\mathrm{GR}_{7} \sim 20\right)$, condensation sink (CS), sulfuric acid proxy $\left(\left[\mathrm{H}_{2} \mathrm{SO}_{4}\right]\right)$, number concentrations of 1.34-3 nm clusters/particles $\left(N_{1.34 \sim 3}\right)$, and total number concentrations of particles $\left(N_{1.34 \sim 615}\right)$, of each NPF event during this campaign.

\begin{tabular}{|c|c|c|c|c|c|c|c|c|c|c|}
\hline Date & $\begin{array}{r}J_{1.34} \\
\left(\mathrm{~cm}^{-3} \mathrm{~s}^{-1}\right)\end{array}$ & $\begin{array}{r}J_{3} \\
\left(\mathrm{~cm}^{-3} \mathrm{~s}^{-1}\right)\end{array}$ & $\begin{array}{r}\mathrm{GR}_{1.35 \sim 2.39} \\
\quad\left(\mathrm{~nm} \mathrm{~h}^{-1}\right)\end{array}$ & $\begin{array}{l}\mathrm{GR}_{2.39 \sim 7} \\
\left(\mathrm{~nm} \mathrm{~h}^{-1}\right)\end{array}$ & $\begin{array}{l}\mathrm{GR}_{7 \sim 20} \\
\left(\mathrm{~nm} \mathrm{~h}^{-1}\right)\end{array}$ & $\begin{array}{r}\mathrm{CS}^{\mathrm{e}} \\
\left(10^{-2} \mathrm{~s}^{-1}\right)\end{array}$ & $\begin{array}{r}{\left[\mathrm{H}_{2} \mathrm{SO}_{4}\right]^{\mathrm{e}}} \\
\left(10^{7} \mathrm{~cm}^{-3}\right)\end{array}$ & $\begin{array}{r}N_{1.34 \sim 3^{\mathrm{f}}} \\
\left(10^{4} \mathrm{~cm}^{-3}\right)\end{array}$ & $\begin{array}{l}N_{1.34 \sim 615^{\mathrm{f}}} \\
\left(10^{4} \mathrm{~cm}^{-3}\right)\end{array}$ & Ref. \\
\hline 25 November 2013 & $\mathrm{NA}^{\mathrm{a}}$ & 10.6 & NA & $12.4^{\mathrm{b}}$ & 38.3 & 4.7 & 2.7 & $3.3^{\mathrm{g}}$ & 6.3 & this study \\
\hline 26 November 2013 & NA & 2.3 & NA & $0.32^{\mathrm{b}}$ & NA & 5.9 & 2.6 & NA & NA & this study \\
\hline 28 November 2013 & 185.1 & 13.4 & 0.94 & 35.7 & 4.6 & 5.7 & 3.6 & 1.6 & 4.2 & this study \\
\hline 29 November 2013 & 271.0 & 3.9 & 1.7 & 10.6 & 4.5 & 6.3 & 4.3 & 2.1 & 4.5 & this study \\
\hline 30 November 2013 & NA & NA & 0.82 & 3.4 & 10.2 & NA & 3.1 & 1.5 & NA & this study \\
\hline 10 November 2013 & 268.4 & 10.0 & 0.49 & 18.6 & 21.0 & 9.9 & 5.5 & 1.4 & 4.6 & this study \\
\hline 11 December 2013 & 219.0 & 19.2 & NA & 5.1 & 9.6 & 10.2 & 6.4 & 1.1 & 4.5 & this study \\
\hline 12 December 2013 & 190.3 & 7.6 & NA & 3.1 & 12.3 & 8.8 & 4.5 & 1.1 & 4.1 & this study \\
\hline 9 January 2014 & 136.2 & NA & 8.1 & NA & 9.5 & 3.7 & 2.3 & 1.6 & 3.8 & this study \\
\hline 13 January 2014 & NA & 2.7 & NA & 6.3 & 1.9 & 3.0 & 2.3 & 1.5 & 3.4 & this study \\
\hline 15 January 2014 & 121.9 & NA & 0.56 & NA & 9.7 & 4.2 & 4.1 & 1.5 & 4.3 & this study \\
\hline 21 January 2014 & 112.4 & 9.2 & 1.5 & 11.9 & 7.5 & 4.9 & 3.7 & 1.1 & 3.9 & this study \\
\hline 24 January 2014 & NA & 8.1 & NA & $12.2^{\mathrm{b}}$ & 7.8 & 4.7 & 3.4 & 1.7 & 4.2 & this study \\
\hline Mean & 188.0 & 8.7 & 2.0 & 10.9 & 11.4 & 6.0 & 3.7 & 1.5 & 4.4 & this study \\
\hline Hyytiälä & 1.4 & 0.61 & 1.4 & 3.9 & 4.9 & $0.05-0.35$ & & & & Kulmala et al. (2012) \\
\hline Kent, OH & 1.3 & & & & & 0.8 & & 0.9 & & Yu et al. (2014) \\
\hline Atlanta & & & & & $3-20^{c}$ & & & & & Stolzenburg et al. (2005) \\
\hline Atlanta & & & $5.5-7.6$ & & & & & & & Kuang et al. (2012) \\
\hline Beijing & & & & & $1.2-8.0^{\mathrm{c}}$ & $2.4-3.6$ & & & & Gao et al. (2012) \\
\hline Beijing & & $3.3-81.4$ & & & $0.1-11.2^{\mathrm{c}}$ & $0.58-4.3$ & & & & Wu et al. (2007) \\
\hline Beijing & & & & & $2.7-13.9^{c}$ & $0.6-8.4$ & & & & Zhang et al. (2011) \\
\hline Beijing & & $1.1-22.4$ & & & $1.2-5.6^{\mathrm{c}}$ & $0.9-5.3$ & & & & Yue et al. (2009) \\
\hline Nanjing & $33.2^{\mathrm{h}}$ & $1.1^{\mathrm{i}}$ & & 6.3 & $8^{\mathrm{d}}$ & 2.4 & & & & Herrmann et al. (2014) \\
\hline Hong Kong & & $3.6-6.9$ & & & $1.5-8.4^{\mathrm{c}}$ & $1.0-6.2$ & & & & Guo et al. (2012) \\
\hline & & & & & 4.0-22.7 (rural) & $2.3-3.3$ (rural) & & & & \\
\hline Pearl River delta & & $2.4-4.0$ (rural) & & & $10.1-18.9$ (urban) & $3.5-4.6$ (urban) & & & & Yue et al. (2013) \\
\hline
\end{tabular}

${ }^{a}$ Data were not available or could not be accurately determined; ${ }^{b}$ results were calculated from nano-SMPS data; ${ }^{\mathrm{c}}$ shown here is GR $3 \sim 30$; ${ }^{\mathrm{d}}$ shown here is GR $7 \sim 30$;

${ }^{\mathrm{e}}$ daytime average (from 6:00 a.m. to 6:00 p.m.); ${ }^{\mathrm{f}} 24 \mathrm{~h}$ average; ${ }^{\mathrm{g}}$ average values between $10 \mathrm{a} . \mathrm{m}$. and 4 p.m.; ${ }^{\mathrm{h}}$ shown here is $J_{2}$;

i shown here is $J_{6}$

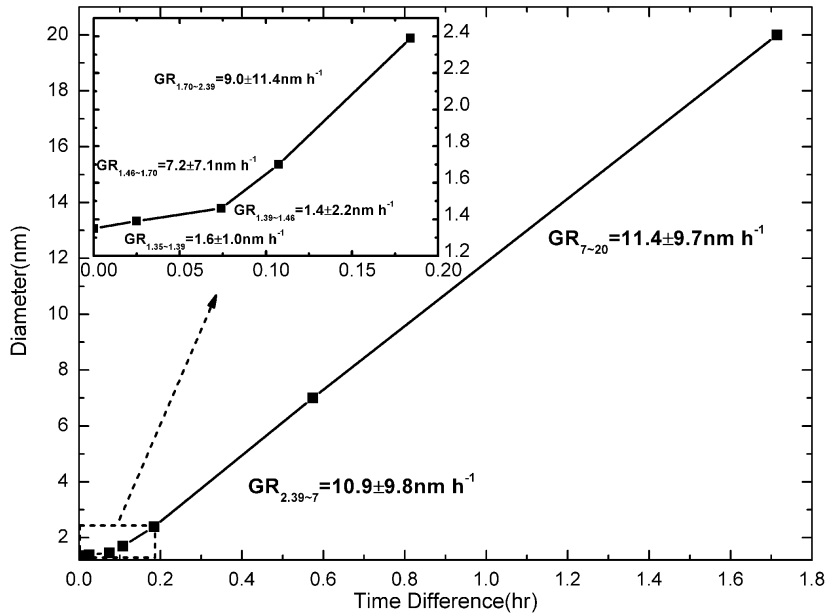

Figure 3. Averaged particle size evolution on NPF days. Arithmetic mean of particle growth rates are given with 1 standard deviation.

\subsection{Potential mechanisms for NPF events}

As shown in Table 1 , nucleation rate $\left(J_{1.34}\right)$ in this study is typically larger than $100 \mathrm{~cm}^{-3} \mathrm{~s}^{-1}$, suggesting that the ion-induced nucleation was not a main mechanism for observed fast nucleation (Hirsikko et al., 2011; Riccobono et al., 2014). The 2012 winter study at the SORPES-NJU sta- tion that is also located at YRD shows that the ratio of $J_{2}$ between ions and total particles (ions plus neutral particles) was 0.002 , also indicating the minor role of ion-induced nucleation (Herrmann et al., 2014). Hence, it is likely that nucleation of neutral precursor molecules actually largely determined the observed NPF events.

Correlations between $\log J_{1.34}$ and $\log \left[\mathrm{H}_{2} \mathrm{SO}_{4}\right]$ (Fig. 4) and between $\log J_{1.34}$ and $\log \left[\mathrm{NH}_{3}\right]$ (Fig. 5) were examined to elucidate potential mechanisms for our NPF events. Since $J_{1.34}$ could not be accurately determined on some of the NPF days, the number of data points in both figures was less than the actual number of NPF events that have been observed. Daily peak concentration of sulfuric acid proxy and daytime (6 a.m.-6 p.m.) averages of ammonia were used as approximations for their effective concentrations on a NPF day since there was no peak concentration for ammonia. The correlation $\left(R^{2}=0.62\right)$ between $\log J_{1.34}$ and $\log \left[\mathrm{NH}_{3}\right]$ is better than that $\left(R^{2}=0.38\right)$ between $\log J_{1.34}$ and $\log \left[\mathrm{H}_{2} \mathrm{SO}_{4}\right]$, and slopes are $0.57 \pm 0.17$ and $0.65 \pm 0.28$, respectively.

Most ambient studies showed that nucleation rate $J$ is proportional to the first or second power of the concentration of gas-phase sulfuric acid, i.e., $J=A \cdot\left[\mathrm{H}_{2} \mathrm{SO}_{4}\right]^{P}$ where $P$ is equal to 1 or 2 , conventionally interpreted as the number of sulfuric acid molecules in the critical nucleus, and $A$ is a pre-exponential factor (McMurry et al., 2005; Sihto et al., 2006; Erupe et al., 2010). Our $P$ of $0.65 \pm 0.28$ is of a significant uncertainty, which could come from the uncer- 


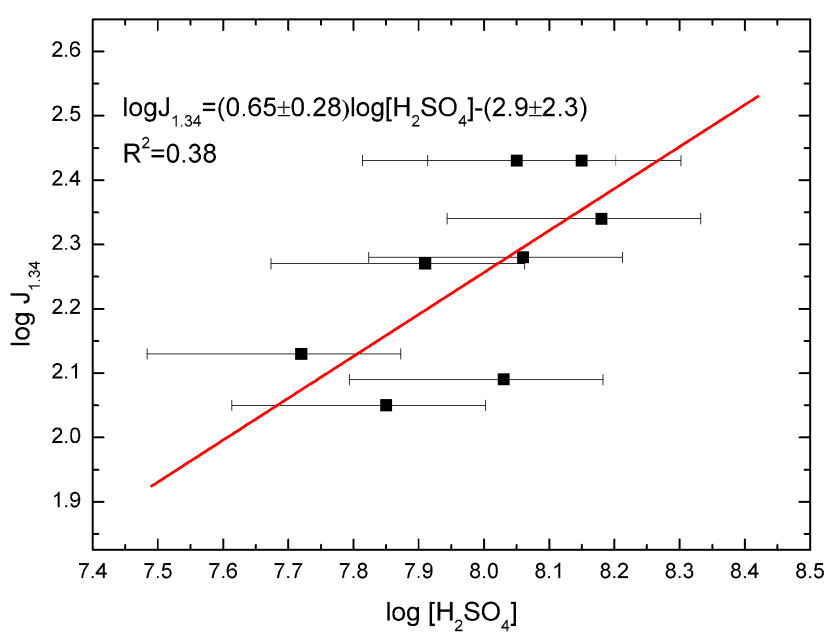

Figure 4. Correlation between $\log J_{1.34}$ and $\log \left[\mathrm{H}_{2} \mathrm{SO}_{4}\right]$. Daily peak concentration of sulfuric acid proxy was used as an approximation for its effective concentration on a NPF day. The error bar corresponds to a $42 \%$ uncertainty of sulfuric acid proxy according to Mikkonen et al. (2011).

tainty during the calculation of sulfuric acid proxy $\left[\mathrm{H}_{2} \mathrm{SO}_{4}\right]$ and the scarcity of our data points. The upper limit of our $P$ indicates that nucleation occurs after activation of clusters containing one molecule of sulfuric acid, with subsequent growth involving other species (Kulmala et al., 2006). The lower limit, however, would imply a less important role of sulfuric acid in the critical nucleus during our campaign, which is unlikely to be true according to numerous previous studies (Weber et al., 1996; Sipila et al., 2010; Yu and Hallar, 2014). Kupiainen-Määttä et al. (2014) recently reported that the number of molecules in a critical cluster cannot be determined by a slope analysis in atmospherically relevant applications, underscoring the need to further explore the exact nucleation mechanism. Herrmann et al. (2014) also calculated the sulfuric acid proxy, related it to observed nucleation rates, and speculated that the sulfuric acid exponent might be well over 2, which underscores the reliability of calculation methods in a Chinese location. Hence, our preliminary result should be further tested with actual measurements of gas-phase sulfuric acid, although it does indicate the key role of sulfuric acid in NPF events. On the one hand, linear correlation between $\log J$ and $\log \left[\mathrm{NH}_{3}\right]$ was observed in a previous nucleation study in Atlanta, GA, with a slope of 1.17 (McMurry et al., 2005); on the other hand, a clear relationship was not perceived in Kent, OH (Erupe et al., 2010). This discrepancy may come from the level of ammonia that has been predicted to have a saturation threshold (Napari et al., 2002) and/or the co-existing sulfuric acid concentration (Benson et al., 2009). Nevertheless, our correlation between $\log J$ and $\log \left[\mathrm{NH}_{3}\right]$ suggests that ammonia also participated in the nucleation. A recent chemical ionization mass spectrometer (CIMS) study (Zheng et al., 2015) observed good

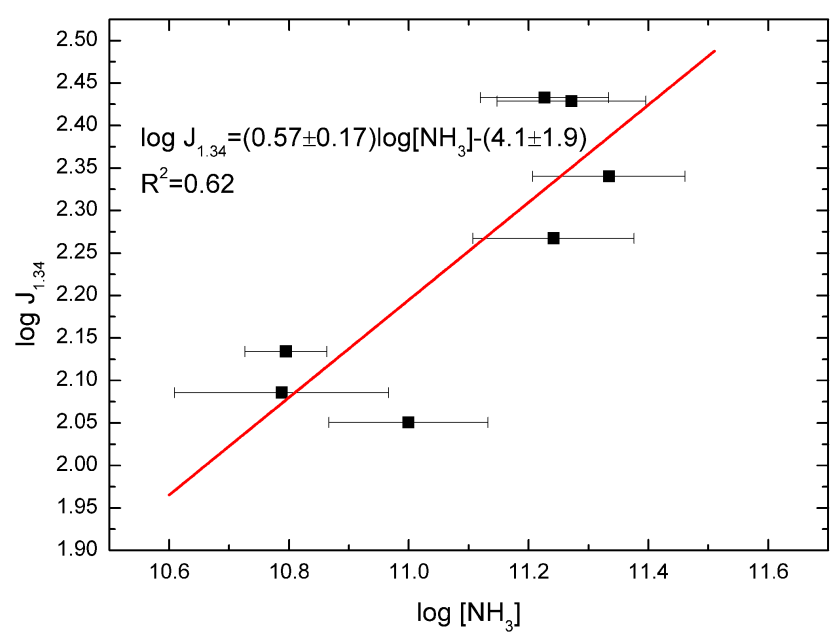

Figure 5. Correlation between $\log J_{1.34}$ and $\log \left[\mathrm{NH}_{3}\right]$. Daytime average of ammonia was used as an approximation for its effective concentration on a NPF day. The error bar represents the standard deviation of the daytime average concentration of ammonia.

correlations between $\mathrm{NH}_{3}$ and amines at an urban site in Nanjing, China. Hence, it is plausible that amines may contribute to nucleation in our site in Shanghai, too.

The subsequent growth of newly formed particles can be partially attributed to condensation of sulfuric acid. The theoretical maximum growth rate of $1.34-3 \mathrm{~nm}$ clusters/particles due to condensation of hydrated sulfuric acid at $50 \% \mathrm{RH}\left(\mathrm{GR}_{\mathrm{H}_{2} \mathrm{SO}_{4}(1.34 \sim 3)}\right)$, calculated according to Eqs. (6) and (7), was $3.9 \pm 1.3 \mathrm{~nm} \mathrm{~h}^{-1}$ on average. This rate is larger than the observed growth rates of clusters/particles from the bin of $1.34-1.37 \mathrm{~nm}$ to the bin of $1.89-3.0 \mathrm{~nm}$ $\left(\mathrm{GR}_{1.35 \sim 2.39}\right)$, being $2.0 \pm 2.7 \mathrm{~nm} \mathrm{~h}^{-1}$, indicating that sulfuric acid proxy was enough to explain the observed growth for particles under $3 \mathrm{~nm}$. Similar calculation of $\mathrm{GR}_{\mathrm{H}_{2} \mathrm{SO}_{4}(3 \sim 7)}$ and $\mathrm{GR}_{\mathrm{H}_{2} \mathrm{SO}_{4}(7 \sim 20)}$ yielded $2.8 \pm 0.94$ and $2.2 \pm 0.74 \mathrm{~nm} \mathrm{~h}^{-1}$, respectively. In Fig. 6, relative contributions of sulfuric acid to growth of particles in the range of 3-7 and 7-20 nm on each NPF day is presented. Since $7 \mathrm{~nm}$ particles reached their maximum earlier than $3 \mathrm{~nm}$ particles on 9 and 15 January 2014, there was no calculated $\mathrm{GR}_{3 \sim 7}$ and hence no ratios available on these 2 days. In addition, condensation of hydrated sulfuric acid was more prominent for 3-7 nm particles on 6 NPF days $(25,26$, and 30 November, and 10, 11, and 12 December 2013), whereas it was more significant for 7-20 nm particles on the other 5 NPF days (28, 29 November 2013, and 13, 21, and 24 January 2014). On average, condensation of gas-phase hydrated sulfuric acid explained $39.1 \%$ of $\mathrm{GR}_{2.39 \sim 7}$ and $29.0 \%$ of $\mathrm{GR}_{7 \sim 20}$. The rest of growth might be largely attributed to condensation of extremely low volatility organic compounds (Ehn et al., 2014) and potentially heterogeneous reactions of organics on nanoparticle surface (Wang et al., 2010, 2011). 


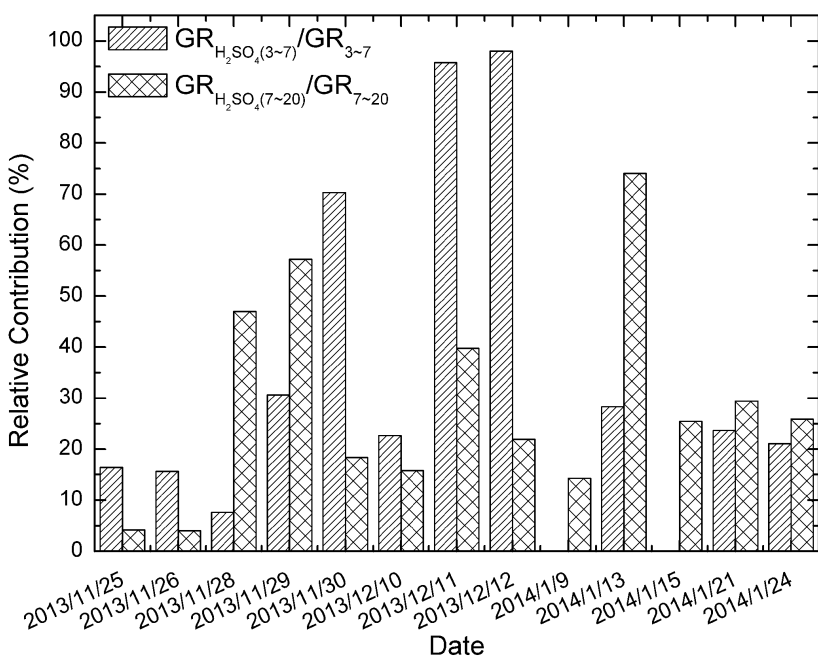

Figure 6. Relative contribution of sulfuric acid to growth of particles in the range of 3-7 and 7-20 nm, respectively, on each NPF day.

\subsection{NPF and aerosol surface area}

NPF events in urban environments are of special interest since the pre-existing particle surface may significantly scavenge the newly formed particles and change the probability of NPF. We plot number concentrations of $1.34-10 \mathrm{~nm}$ particles $\left(N_{1.34 \sim 10}\right)$, sulfuric acid proxy $\left(\left[\mathrm{H}_{2} \mathrm{SO}_{4}\right]\right)$, ammonia ([NH $\left.\mathrm{NH}_{3}\right]$ ), and aerosol surface area with shadowed blocks representing NPF events in Fig. 7. Note that $N_{1.34 \sim 10}$ was used as an approximation for nucleation and subsequent growth while excluding particles from direct emission. The average daytime (6 a.m. -6 p.m.) $N_{1.34 \sim 10}$ on NPF days was ( $2.7 \pm$ $2.1 \times 10^{4} \mathrm{~cm}^{-3}$, much larger than $(1.5 \pm 1.0) \times 10^{4} \mathrm{~cm}^{-3}$ on the rest days of the campaign, indicating that a stronger input of particles from nucleation processes on NPF days. However, daytime $\left[\mathrm{H}_{2} \mathrm{SO}_{4}\right]$ did not show an apparent difference between on NPF days $\left((3.7 \pm 1.2) \times 10^{7}\right.$ molecules $\left.\mathrm{cm}^{-3}\right)$ and on the rest days $\left((3.9 \pm 2.5) \times 10^{7}\right.$ molecules $\left.\mathrm{cm}^{-3}\right)$. For example, an episode with high daily sulfuric acid proxy during 19 December 2013 and 16 January 2014 did not lead to any NPF events. Instead, observed NPF events occurred on days with low aerosol surface area levels and moderate $\left[\mathrm{H}_{2} \mathrm{SO}_{4}\right]$. During our campaign, NPF days were characterized with low aerosol surface area $\left((7.8 \pm 3.8) \times 10^{8} \mathrm{~nm}^{2} \mathrm{~cm}^{-3}\right)$, whereas the average was $(10.4 \pm 4.7) \times 10^{8} \mathrm{~nm}^{2} \mathrm{~cm}^{-3}$ on the rest days of the campaign. Ammonia varied dramatically, even within a single day. NPF events occurred on days with around 10fold difference in ammonia concentrations. According to ammonia's profile and its positive correlation with $J_{1.34}$, we speculate that ammonia was involved in nucleation but was not the driving force.

Examination of these parameters was performed from 12 to 14 January 2014 because the 3 days were characterized with similar meteorological conditions. The average day- time concentration of sulfuric acid proxy was $2.8,2.3$, and $1.0 \times 10^{7}$ molecules $\mathrm{cm}^{-3}$ on 12,13 , and 14 January 2014 , respectively. No NPF event was observed on 14 January at least partially because of the low sulfuric acid proxy. Appearance of a NPF event on 13 January and non-appearance on 12 January could be explained by the high aerosol surface area on 12 January, with maximum aerosol surface area up to $1.8 \times 10^{9} \mathrm{~nm}^{2} \mathrm{~cm}^{-3}$, although similar sulfuric acid proxies existed between the 2 days. Hence, we conclude that, qualitatively, NPF processes in urban Shanghai occurred with low levels of aerosol surface and that high sulfuric acid favored NPF events when aerosol surface area was low. This conclusion is identical to that drawn from a Mexico City study where NPF events observed in the city correlated with elevated concentrations of sulfur dioxide and low particulate matter mass concentrations in the afternoon hours (Dunn et al., 2004).

\section{Summary and conclusions}

Atmospheric new particle formation is a significant source of atmospheric aerosol particles. Understanding NPF under the current levels of air pollution in China is of special scientific interest because the exact nucleation mechanism under urban environment remains elusive. From 25 November 2013 to 25 January 2014, a combination of one nCNC, one nano-SPMS, and one long-SPMS has been utilized to investigate atmospheric nucleation by measuring particle size distributions in the range of $1.34-615 \mathrm{~nm}$ in urban Shanghai, located in the east Yangtze River delta. During this 62-day campaign, 13 NPF events were identified with strong burst of sub-3 nm particles and subsequent fast growth of newly formed particles. Together with nucleation frequency (21\%), the obtained nucleation rate $J_{1.34}\left(112.4-271.0 \mathrm{~cm}^{-3} \mathrm{~s}^{-1}\right)$, condensation sink $\left(0.030-0.10 \mathrm{~s}^{-1}\right)$, and aerosol surface area $\left((7.8 \pm 3.8) \times 10^{8} \mathrm{~nm}^{2} \mathrm{~cm}^{-3}\right)$ on NPF event days clearly indicate that strong atmospheric new particle formation occurred in winter in urban Shanghai, with competition between promotion from condensable vapors and scavenging by preexisting particles. The absolute values of $J_{1.34}$ and CS are 1 to 2 orders of magnitude larger than those at locations with a pristine atmosphere (e.g., Kulmala et al., 2012) and semirural locations with very low pollution levels such as Kent, $\mathrm{OH}$ (Yu et al., 2014), as a reflection of the significantly altered atmospheric background.

Our preliminary exploration of the nucleation mechanism indicated that nucleation rate $J_{1.34}$ was proportional to a $0.65 \pm 0.28$ power of sulfuric acid proxy. It is hence likely that observed NPF events could be explained by the activation theory. As Herrmann et al. (2014) doubted reliability of sulfuric acid proxy, accurate measurements of gas-phase sulfuric acid instead of calculation of a proxy is necessary to achieve an unambiguous conclusion. The positive correlation between $J_{1.34}$ and gas-phase ammonia hints at the involve- 


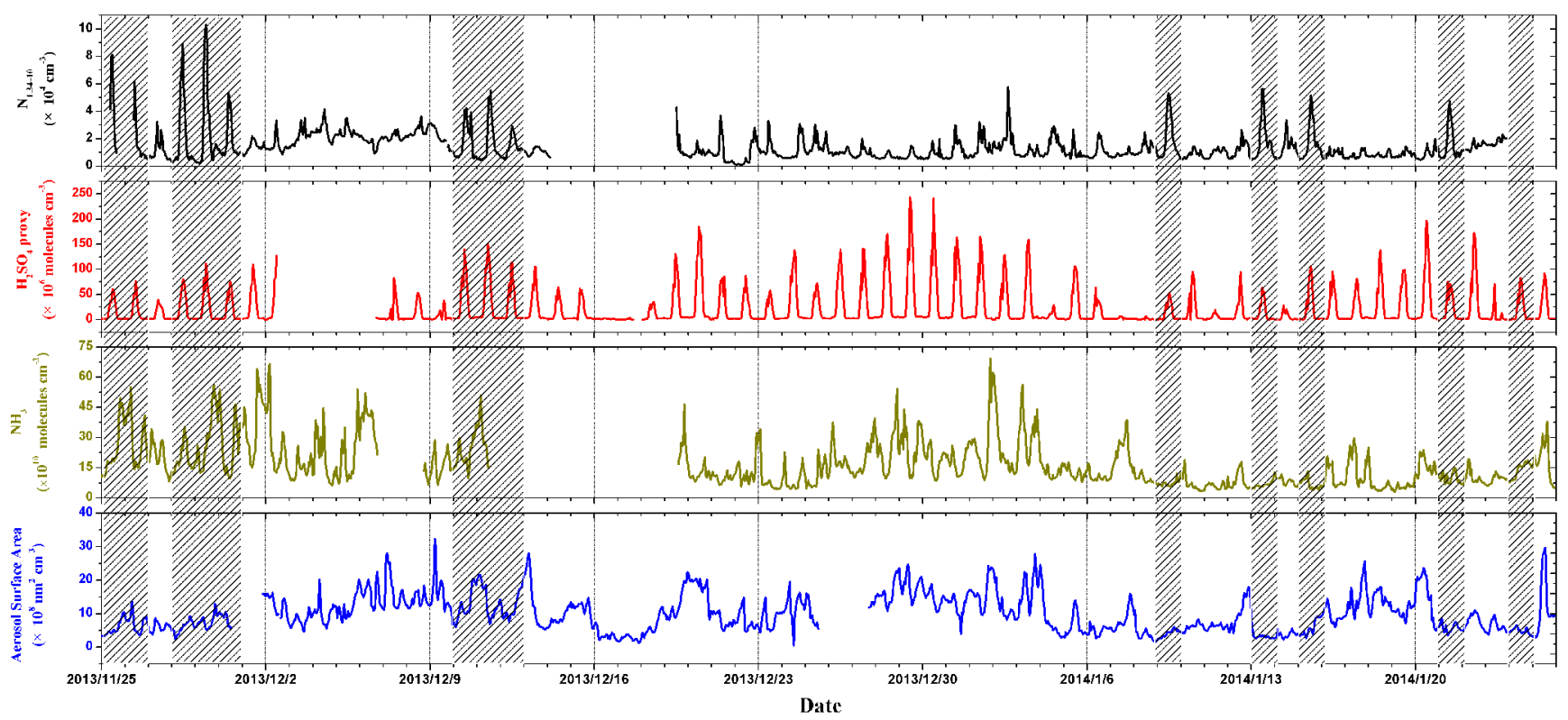

Figure 7. Number concentrations of $1.34-10 \mathrm{~nm}$ particles $\left(N_{1.34 \sim 10}\right)$, sulfuric acid proxy $\left(\left[\mathrm{H}_{2} \mathrm{SO}_{4}\right]\right)$, concentrations of ammonia, and aerosol surface area during the campaign. NPF events are illustrated with shadows.

ment of ammonia in new particle formation, but its exact role cannot be determined without measurements of nucleating clusters.

A size-dependent particle growth in the range of 1.34$20 \mathrm{~nm}$ has been observed in this study, consistent with predictions from nano-Köhler theory (Kulmala et al., 2004a) and Kelvin-limited diffusion, surface, and volume growth laws (Kuang et al., 2012). Sulfuric acid proxy was enough to explain the observed growth for particles under $3 \mathrm{~nm}$ and contributed to 39.1 of $\mathrm{GR}_{2.39 \sim 7}$ and $29.0 \%$ of $\mathrm{GR}_{7 \sim 20}$. The rest of the growth could be largely attributed to condensation of extremely low volatility organic compounds (Ehn et al., 2014) and potentially heterogeneous reactions of organics on nanoparticle surface (Wang et al., 2010, 2011).

Clearly, further long-term measurements with integrated state-of-the-art measurement techniques are necessary to draw a comprehensive picture of atmospheric nucleation events in China. Currently, atmospheric sub- $3 \mathrm{~nm}$ particle measurements are still scarce in China, other than measurements of gas-phase sulfuric acid, nucleating clusters, and other potential precursors. Nevertheless, our study offers the very first measurement of sub-3 $\mathrm{nm}$ particles in urban Shanghai and provides some of the preliminary mechanisms for NPF events in China.
Acknowledgements. This study was financially supported by the National Natural Science Foundation of China (no. 21107015, 21190053, 21277029, and 21222703), the Ministry of Science and Technology of China (2012YQ220113-4), the Science and Technology Commission of Shanghai Municipality (12DJ1400100), and the Cyrus Tang Foundation. LW thanks the Jiangsu Provincial 2011 Program (Collaborative Innovation Center of Climate Change).

Edited by: J. Allan

\section{References}

Andreae, M. O. and Crutzen, P. J.: Atmospheric aerosols: biogeochemical sources and role in atmospheric chemistry, Science, 276, 1052-1058, 1997.

Anttila, T., Kerminen, V.-M., and Lehtinen, K. E. J.: Parameterizing the formation rate of new particles: the effect of nuclei self-coagulation, J. Aerosol Sci., 41, 621-636, doi:10.1016/j.jaerosci.2010.04.008, 2010.

Ball, S., Hanson, D., Eisele, F., and McMurry, P.: Laboratory studies of particle nucleation: Initial results for $\mathrm{H}_{2} \mathrm{SO}_{4}, \mathrm{H}_{2} \mathrm{O}$, and $\mathrm{NH}_{3}$ vapors, J. Geophys. Res.-Atmos., 104, 23709-23718, 1999.

Benson, D. R., Erupe, M. E., and Lee, S. H.: Laboratorymeasured $\mathrm{H}_{2} \mathrm{SO}_{4}-\mathrm{H}_{2} \mathrm{O}-\mathrm{NH}_{3}$ ternary homogeneous nucleation rates: Initial observations, Geophys. Res. Lett., 36, L15818, doi:10.1029/2009GL038728, 2009.

Berndt, T., Stratmann, F., Sipilä, M., Vanhanen, J., Petäjä, T., Mikkilä, J., Grüner, A., Spindler, G., Lee Mauldin III, R., Curtius, J., Kulmala, M., and Heintzenberg, J.: Laboratory study on new particle formation from the reaction $\mathrm{OH}+\mathrm{SO}_{2}$ : influence of experimental conditions, $\mathrm{H}_{2} \mathrm{O}$ vapour, $\mathrm{NH}_{3}$ and the amine tert-butylamine on the overall process, Atmos. Chem. Phys., 10, 7101-7116, doi:10.5194/acp-10-7101-2010, 2010. 
Chan, C. K. and Yao, X.: Air pollution in mega cities in China, Atmos. Environ., 42, 1-42, 2008.

Dal Maso, M. D., Kulmala, M., Riipinen, I., Wagner, R., Hussein, T., Aalto, P. P., and Lehtinen, K. E.: Formation and growth of fresh atmospheric aerosols: eight years of aerosol size distribution data from SMEAR II, Hyytiälä, Finland, Boreal Environ. Res., 10, 323-336, 2005.

Dockery, D. W., Pope, C. A., Xu, X., Spengler, J. D., Ware, J. H., Fay, M. E., Ferris Jr, B. G., and Speizer, F. E.: An association between air pollution and mortality in six US cities, New Engl. J. Med., 329, 1753-1759, 1993.

Du, J., Cheng, T., Zhang, M., Chen, J., He, Q., Wang, X., Zhang, R., Tao, J., Huang, G., and Li, X.: Aerosol Size Spectra and Particle Formation Events at Urban Shanghai in Eastern China, Aerosol Air Qual. Res, 12, 1362-1372, 2012.

Dunn, M. J., Jiménez, J. L., Baumgardner, D., Castro, T., McMurry, P. H., and Smith, J. N.: Measurements of Mexico City nanoparticle size distributions: Observations of new particle formation and growth, Geophys. Res. Lett., 31, L10102, doi:10.1029/2004GL019483, 2004.

Ehn, M., Thornton, J. A., Kleist, E., Sipilä, M., Junninen, H., Pullinen, I., Springer, M., Rubach, F., Tillmann, R., and Lee, B.: A large source of low-volatility secondary organic aerosol, Nature, 506, 476-479, 2014.

Eisele, F. and Tanner, D.: Measurement of the gas phase concentration of $\mathrm{H}_{2} \mathrm{SO}_{4}$ and methane sulfonic acid and estimates of $\mathrm{H}_{2} \mathrm{SO}_{4}$ production and loss in the atmosphere, J. Geophys. Res.Atmos., 98, 9001-9010, 1993.

Erupe, M. E., Benson, D. R., Li, J., Young, L.-H., Verheggen, B., Al-Refai, M., Tahboub, O., Cunningham, V., Frimpong, F., Viggiano, A. A., and Lee, S.-H.: Correlation of aerosol nucleation rate with sulfuric acid and ammonia in Kent, Ohio: An atmospheric observation, J. Geophys. Res., 115, D23216, doi:10.1029/2010jd013942, 2010.

Gao, J., Chai, F., Wang, T., Wang, S., and Wang, W.: Particle number size distribution and new particle formation: New characteristics during the special pollution control period in Beijing, J. Environ. Sci., 24, 14-21, doi:10.1016/s1001-0742(11)60725-0, 2012.

Guo, H., Wang, D. W., Cheung, K., Ling, Z. H., Chan, C. K., and Yao, X. H.: Observation of aerosol size distribution and new particle formation at a mountain site in subtropical Hong Kong, Atmos. Chem. Phys., 12, 9923-9939, doi:10.5194/acp-12-99232012, 2012.

Haywood, J. and Boucher, O.: Estimates of the direct and indirect radiative forcing due to tropospheric aerosols: a review, Rev. Geophys., 38, 513-543, doi:10.1029/1999rg000078, 2000.

Herrmann, E., Ding, A. J., Kerminen, V.-M., Petäjä, T., Yang, X. Q., Sun, J. N., Qi, X. M., Manninen, H., Hakala, J., Nieminen, T., Aalto, P. P., Kulmala, M., and Fu, C. B.: Aerosols and nucleation in eastern China: first insights from the new SORPES-NJU station, Atmos. Chem. Phys., 14, 2169-2183, doi:10.5194/acp14-2169-2014, 2014.

Hirsikko, A., Nieminen, T., Gagné, S., Lehtipalo, K., Manninen, H. E., Ehn, M., Hõrrak, U., Kerminen, V.-M., Laakso, L., McMurry, P. H., Mirme, A., Mirme, S., Petäjä, T., Tammet, H., Vakkari, V., Vana, M., and Kulmala, M.: Atmospheric ions and nucleation: a review of observations, Atmos. Chem. Phys., 11, 767798, doi:10.5194/acp-11-767-2011, 2011.
IPCC: IPCC, 2013: Climate change 2013: The physical science basis, Contribution of working group I to the fourth assessment report of the intergovernmental panel on climate change, Cambridge University Press, Cambridge, United Kingdom and New York, NY, USA, 2013.

Kanawade, V. P., Benson, D. R., and Lee, S.-H.: Statistical analysis of 4-year observations of aerosol sizes in a semirural continental environment, Atmos. Environ., 59, 30-38, doi:10.1016/j.atmosenv.2012.05.047, 2012.

Korhonen, H., Sihto, S.-L., Kerminen, V.-M., and Lehtinen, K. E. J.: Evaluation of the accuracy of analysis tools for atmospheric new particle formation, Atmos. Chem. Phys., 11, 3051-3066, doi:10.5194/acp-11-3051-2011, 2011.

Kuang, C., Chen, M., Zhao, J., Smith, J., McMurry, P. H., and Wang, J.: Size and time-resolved growth rate measurements of 1 to $5 \mathrm{~nm}$ freshly formed atmospheric nuclei, Atmos. Chem. Phys., 12, 3573-3589, doi:10.5194/acp-12-3573-2012, 2012.

Kulmala, M., Toivonen, A., Mäkelä, J. M., and Laaksonen, A.: Analysis of the growth of nucleation mode particles observed in Boreal forest, Tellus B, 50, 449-462, 1998.

Kulmala, M., Kerminen, V. M., Anttila, T., Laaksonen, A., and O'Dowd, C. D.: Organic aerosol formation via sulphate cluster activation, J. Geophys. Res.-Atmos., 109, D04205, doi:10.1029/2003JD003961, 2004a.

Kulmala, M., Vehkamäki, H., Petäjä, T., Dal Maso, M., Lauri, A., Kerminen, V. M., Birmili, W., and McMurry, P. H.: Formation and growth rates of ultrafine atmospheric particles: a review of observations, J. Aerosol Sci., 35, 143-176, doi:10.1016/j.jaerosci.2003.10.003, 2004b.

Kulmala, M., Lehtinen, K. E. J., and Laaksonen, A.: Cluster activation theory as an explanation of the linear dependence between formation rate of $3 \mathrm{~nm}$ particles and sulphuric acid concentration, Atmos. Chem. Phys., 6, 787-793, doi:10.5194/acp-6-787-2006, 2006.

Kulmala, M., Riipinen, I., Sipilä, M., Manninen, H. E., Petäjä, T., Junninen, H., Dal Maso, M., Mordas, G., Mirme, A., and Vana, M.: Toward direct measurement of atmospheric nucleation, Science, 318, 89-92, 2007.

Kulmala, M., Petäjä, T., Nieminen, T., Sipilä, M., Manninen, H. E., Lehtipalo, K., Dal Maso, M., Aalto, P. P., Junninen, H., Paasonen, P., Riipinen, I., Lehtinen, K. E. J., Laaksonen, A., and Kerminen, V.-M.: Measurement of the nucleation of atmospheric aerosol particles, Nat. Protoc., 7, 1651-1667, doi:10.1038/nprot.2012.091, 2012.

Kulmala, M., Kontkanen, J., Junninen, H., Lehtipalo, K., Manninen, H. E., Nieminen, T., Petaja, T., Sipila, M., Schobesberger S., Rantala, P., Franchin, A., Jokinen, T., Jarvinen, E., Aijala, M., Kangasluoma, J., Hakala, J., Aalto, P. P., Paasonen, P., Mikkila, J., Vanhanen, J., Aalto, J., Hakola, H., Makkonen, U., Ruuskanen, T., Mauldin, R. L., Duplissy, J., Vehkamaki, H., Back, J., Kortelainen, A., Riipinen, I., Kurten, T., Johnston, M. V., Smith, J. N., Ehn, M., Mentel, T. F., Lehtinen, K. E. J., Laaksonen, A., Kerminen, V. M., and Worsnop, D. R.: Direct Observations of Atmospheric Aerosol Nucleation, Science, 339, 943 946, doi:10.1126/science.1227385, 2013.

Kupiainen-Määttä, O., Olenius, T., Korhonen, H., Malila, J., Dal Maso, M., Lehtinen, K., and Vehkamäki, H.: Critical cluster size cannot in practice be determined by slope analysis in atmo- 
spherically relevant applications, J. Aerosol Sci., 77, 127-144, doi:10.1016/j.jaerosci.2014.07.005, 2014.

Kurtén, T., Noppel, M., Vehkamaeki, H., Salonen, M., and Kulmala, M.: Quantum chemical studies of hydrate formation of $\mathrm{H}_{2} \mathrm{SO}_{4}$ and $\mathrm{HSO}_{4}^{-}$, Boreal Environ. Res., 12, 431-453, 2007.

Laden, F., Schwartz, J., Speizer, F. E., and Dockery, D. W.: Reduction in fine particulate air pollution and mortality: extended follow-up of the Harvard Six Cities study, Am. J. Resp. Crit.Care, 173, 667-672, 2006.

Lee, S.-H., Reeves, J., Wilson, J., Hunton, D., Viggiano, A., Miller, T., Ballenthin, J., and Lait, L.: Particle formation by ion nucleation in the upper troposphere and lower stratosphere, Science, 301, 1886-1889, 2003.

Lehtinen, K. E. J. and Kulmala, M.: A model for particle formation and growth in the atmosphere with molecular resolution in size, Atmos. Chem. Phys., 3, 251-257, doi:10.5194/acp-3-251-2003, 2003.

Ma, Y., Xu, X., Song, W., Geng, F., and Wang, L.: Seasonal and diurnal variations of particulate organosulfates in urban Shanghai, China, Atmos. Environ., 85, 152-160, 2014.

Matsui, H., Koike, M., Kondo, Y., Takegawa, N., Wiedensohler, A., Fast, J. D., and Zaveri, R. A.: Impact of new particle formation on the concentrations of aerosols and cloud condensation nuclei around Beijing, J. Geophys. Res.-Atmos., 116, D19208, doi:10.1029/2011JD016025, 2011.

McMurry, P. H., Fink, M., Sakurai, H., Stolzenburg, M., Mauldin, R., Smith, J., Eisele, F., Moore, K., Sjostedt, S., and Tanner, D.: A criterion for new particle formation in the sulfur-rich Atlanta atmosphere, J. Geophys. Res.-Atmos., 110, D22S02, doi:10.1029/2005JD005901, 2005.

Mikkonen, S., Romakkaniemi, S., Smith, J. N., Korhonen, H., Petäjä, T., Plass-Duelmer, C., Boy, M., McMurry, P. H., Lehtinen, K. E. J., Joutsensaari, J., Hamed, A., Mauldin III, R. L., Birmili, W., Spindler, G., Arnold, F., Kulmala, M., and Laaksonen, A.: A statistical proxy for sulphuric acid concentration, Atmos. Chem. Phys., 11, 11319-11334, doi:10.5194/acp-11-11319-2011, 2011.

Napari, I., Noppel, M., Vehkamäki, H., and Kulmala, M.: Parametrization of ternary nucleation rates for $\mathrm{H}_{2} \mathrm{SO}_{4}-\mathrm{NH}_{3}-$ $\mathrm{H}_{2} \mathrm{O}$ vapors, J. Geophys. Res.-Atmos., 107, AAC 6-1-AAC 6-6, 2002.

Nieminen, T., Lehtinen, K. E. J., and Kulmala, M.: Sub-10 nm particle growth by vapor condensation -effects of vapor molecule size and particle thermal speed, Atmos. Chem. Phys., 10, 9773-9779, doi:10.5194/acp-10-9773-2010, 2010.

O’Dowd, C. D., Jimenez, J. L., Bahreini, R., Flagan, R. C., Seinfeld, J. H., Hämeri, K., Pirjola, L., Kulmala, M., Jennings, S. G., and Hoffmann, T.: Marine aerosol formation from biogenic iodine emissions, Nature, 417, 632-636, 2002.

Park, J., Sakurai, H., Vollmers, K., and McMurry, P. H.: Aerosol size distributions measured at the South Pole during ISCAT, Atmos. Environ., 38, 5493-5500, 2004.

Platt, U. and Stutz, J.: Differential Optical Absorption Spectroscopy-Principles and Applications, Springer Berlin Heidelberg, 2008.

Pope, C. A. and Dockery, D. W.: Health effects of fine particulate air pollution: lines that connect, Japca. J. Air Waste Ma., 56, 709742, 2006

Riccobono, F., Schobesberger, S., Scott, C. E., Dommen, J., Ortega, I. K., Rondo, L., Almeida, J., Amorim, A., Bianchi, F., and
Breitenlechner, M.: Oxidation Products of Biogenic Emissions Contribute to Nucleation of Atmospheric Particles, Science, 344, 717-721, 2014.

Schobesberger, S., Junninen, H., Bianchi, F., Lönn, G., Ehn, M., Lehtipalo, K., Dommen, J., Ehrhart, S., Ortega, I. K., and Franchin, A.: Molecular understanding of atmospheric particle formation from sulfuric acid and large oxidized organic molecules, P. Natl. Acad. Sci. USA, 110, 17223-17228, 2013.

Sihto, S.-L., Kulmala, M., Kerminen, V.-M., Dal Maso, M., Petäjä, T., Riipinen, I., Korhonen, H., Arnold, F., Janson, R., Boy, M., Laaksonen, A., and Lehtinen, K. E. J.: Atmospheric sulphuric acid and aerosol formation: implications from atmospheric measurements for nucleation and early growth mechanisms, Atmos. Chem. Phys., 6, 4079-4091, doi:10.5194/acp-6-4079-2006, 2006.

Sipila, M., Berndt, T., Petaja, T., Brus, D., Vanhanen, J., Stratmann, F., Patokoski, J., Mauldin, R. L., Hyvarinen, A. P., Lihavainen, H., and Kulmala, M.: The Role of Sulfuric Acid in Atmospheric Nucleation, Science, 327, 1243-1246, doi:10.1126/science.1180315, 2010.

Stolzenburg, M. R., McMurry, P. H., Sakurai, H., Smith, J. N., Mauldin, R. L., Eisele, F. L., and Clement, C. F.: Growth rates of freshly nucleated atmospheric particles in Atlanta, J. Geophys. Res., 110, D22S05, doi:10.1029/2005jd005935, 2005.

Vanhanen, J., Mikkilä, J., Lehtipalo, K., Sipilä, M., Manninen, H., Siivola, E., Petäjä, T., and Kulmala, M.: Particle size magnifier for nano-CN detection, Aerosol Sci. Tech., 45, 533-542, 2011.

Wang, L., Khalizov, A. F., Zheng, J., Xu, W., Ma, Y., Lal, V., and Zhang, R.: Atmospheric nanoparticles formed from heterogeneous reactions of organics, Nat. Geosci., 3, 238-242, 2010.

Wang, L., Xu, W., Khalizov, A. F., Zheng, J., Qiu, C., and Zhang, R.: Laboratory investigation on the role of organics in atmospheric nanoparticle growth,J. Phys. Chem. A, 115, 8940-8947, 2011.

Wang, L., Du, H., Chen, J., Zhang, M., Huang, X., Tan, H., Kong, L., and Geng, F.: Consecutive transport of anthropogenic air masses and dust storm plume: Two case events at Shanghai, China, Atmos. Res., 127, 22-33, 2013.

Wang, S., Zhou, R., Zhao, H., Wang, Z., Chen, L., and Zhou, B.: Long-term observation of atmospheric nitrous acid (HONO) and its implication to local $\mathrm{NO}_{2}$ levels in Shanghai, China, Atmos. Environ., 77, 718-724, doi:10.1016/j.atmosenv.2013.05.071, 2013.

Weber, R., Marti, J., McMurry, P., Eisele, F., Tanner, D., and Jefferson, A.: Measured atmospheric new particle formation rates: Implications for nucleation mechanisms, Chem. Eng. Commun., 151, 53-64, 1996.

Wu, Z., Hu, M., Liu, S., Wehner, B., Bauer, S., Ma Bling, A., Wiedensohler, A., Petäjä, T., Dal Maso, M., and Kulmala, M.: New particle formation in Beijing, China: Statistical analysis of a 1-year data set, J. Geophys. Res.-Atmos., 112, D09209, doi:10.1029/2006jd007406, 2007.

Yu, F. and Turco, R. P.: From molecular clusters to nanoparticles: Role of ambient ionization in tropospheric aerosol formation, J. Geophys. Res.-Atmos., 106, 4797-4814, 2001.

Yu, F. Q. and Hallar, A. G.: Difference in particle formation at a mountaintop location during spring and summer: Implications for the role of sulfuric acid and organics in nucleation, J. Geophys. Res.-Atmos., 119, 12246-12255, 2014. 
Yu, H., Gannet Hallar, A., You, Y., Sedlacek, A., Springston, S., Kanawade, V. P., Lee, Y. N., Wang, J., Kuang, C., and McGraw, R. L.: Sub-3 nm particles observed at the coastal and continental sites in the United States, J. Geophys. Res.-Atmos., 119, 860879, doi:10.1002/2013JD020841, 2014.

Yue, D., Hu, M., Wu, Z., Wang, Z., Guo, S., Wehner, B., Nowak, A., Achtert, P., Wiedensohler, A., Jung, J., Kim, Y. J., and Liu, S.: Characteristics of aerosol size distributions and new particle formation in the summer in Beijing, J. Geophys. Res., 114, D00G12, doi:10.1029/2008jd010894, 2009.

Yue, D. L., Hu, M., Zhang, R. Y., Wang, Z. B., Zheng, J., Wu, Z. J., Wiedensohler, A., He, L. Y., Huang, X. F., and Zhu, T.: The roles of sulfuric acid in new particle formation and growth in the mega-city of Beijing, Atmos. Chem. Phys., 10, 4953-4960, doi:10.5194/acp-10-4953-2010, 2010.

Yue, D. L., Hu, M., Zhang, R. Y., Wu, Z. J., Su, H., Wang, Z. B., Peng, J. F., He, L. Y., Huang, X. F., Gong, Y. G., and Wiedensohler, A.: Potential contribution of new particle formation to cloud condensation nuclei in Beijing, Atmos. Environ., 45, 6070-6077, doi:10.1016/j.atmosenv.2011.07.037, 2011.

Yue, D. L., Hu, M., Wang, Z. B., Wen, M. T., Guo, S., Zhong, L. J., Wiedensohler, A., and Zhang, Y. H.: Comparison of particle number size distributions and new particle formation between the urban and rural sites in the PRD region, China, Atmos. Environ., 76, 181-188, doi:10.1016/j.atmosenv.2012.11.018, 2013.

Zhang, R., Suh, I., Zhao, J., Zhang, D., Fortner, E. C., Tie, X., Molina, L. T., and Molina, M. J.: Atmospheric new particle formation enhanced by organic acids, Science, 304, 1487-1490, 2004.
Zhang, R., Wang, L., Khalizov, A. F., Zhao, J., Zheng, J., McGraw, R. L., and Molina, L. T.: Formation of nanoparticles of blue haze enhanced by anthropogenic pollution, P. Natl. Acad. Sci. USA, 106, 17650-17654, 2009.

Zhang, R., Khalizov, A., Wang, L., Hu, M., and Xu, W.: Nucleation and Growth of Nanoparticles in the Atmosphere, Chem. Rev., 112, 1957-2011, doi:10.1021/cr2001756, 2012.

Zhang, Y., Zhang, X., Sun, J., Lin, W., Gong, S., Shen, X., and Yang, S.: Characterization of new particle and secondary aerosol formation during summertime in Beijing, China, Tellus B, 63 , 382-394, 2011.

Zhao, J., Smith, J. N., Eisele, F. L., Chen, M., Kuang, C., and McMurry, P. H.: Observation of neutral sulfuric acid-amine containing clusters in laboratory and ambient measurements, Atmos. Chem. Phys., 11, 10823-10836, doi:10.5194/acp-1110823-2011, 2011.

Zheng, J., Hu, M., Zhang, R., Yue, D., Wang, Z., Guo, S., Li, X., Bohn, B., Shao, M., He, L., Huang, X., Wiedensohler, A., and Zhu, T.: Measurements of gaseous $\mathrm{H}_{2} \mathrm{SO}_{4}$ by AP-ID-CIMS during CAREBeijing 2008 Campaign, Atmos. Chem. Phys., 11, 7755-7765, doi:10.5194/acp-11-7755-2011, 2011.

Zheng, J., Ma, Y., Chen, M., Zhang, Q., Wang, L., Khalizov, A. F., Yao, L., Wang, Z., Wang, X., and Chen, L.: Measurement of atmospheric amines and ammonia using the high resolution timeof-flight chemical ionization mass spectrometry, Atmos. Environ., 102, 249-259, doi:10.1016/j.atmosenv.2014.12.002, 2015. 